\title{
Lexical Creation of Euphemism and Dysphemism in Online Media Text on Presidential Election 2019
}

\author{
Khoirul Hasyim ${ }^{1}$, Nurkamto, Sumarlam ${ }^{3}$, Riyadi Santosa ${ }^{4}$ \\ \{khoirul.hasyim@stkipjb.ac.id\} \\ 1,2,3,4 Sebelas Maret University
}

\begin{abstract}
Euphemism and dysphemism as it used by online media become an interesting phenomenon, mainly when it was used as political weapon. Presidential election of Republic Indonesia on 2019 which was held on April 2019 cannot be separated from online media. Each party, candidate trough online media try to figure out their performance in order to raise voters. Maintaining face by using euphemism become the choice to avoid mistake and also blurred their idea. Furthermore, insulting opponent and evaluating their program, dysphemism is preferred. Online media, in line with the presidential election presented varies lexical creation of euphemism and dysphemism. Keith Allan and Kate Burridge have done many studies on euphemisms. Related to the phenomenon of theoretical euphemisms of this study would follow Keith Allan and Kate Burridge statements and several researchers who were concerned. The data were obtained from four online media, they are DetikNews, SindoNews, TribunNews, and CNN Indonesia and were analyzed by using framing analysis and also content analysis. The result of the research showed that the lexical creation of euphemism was: lexical mitigating, loan words and metaphorical equation. While the lexical creation of dysphemism was: lexical mitigation, metaphorical equation, and hyperbole.
\end{abstract}

Keywords: lexical creation, euphemism, dysphemism, online media, presidential election

\section{Introduction}

Online media often contain expressions of euphemism to refine meaning in order to avoid conflict [1] and [2] and dysphemism which are direct expressions instead of neutral expressions and have connotations of meaning that offend directly [3]. The expression of dysphemism is used to denigrate and humiliate or express disapproval of opponents and other matters. Online media in using lingual expressions that are impolite and connote to something that can attack or being impolite with a specific purpose can trigger a bad communication process. Conversely, the use of polite lingual expression by avoiding lexical that are less acceptable in terms of politeness can make the communication process better [4] so that the message can be conveyed and understood properly. However, in order to attract public attention, the use of dysphemism is also being the choice of the online media in providing news. 
The lexical creations of euphemism and dysphemism are differently applied by online media because they have many ways in delivering news. Initially euphemism was considered as a certain lexical form which replaced taboo, attacking, and hurting. However, in its development, the emergence of euphemism is not only as a lexical substitute for certain lexical but also as a cognitive process produced by certain contexts [5] to avoid undesirable things in a process of communication between speakers and hearer.

The lexical creations of euphemisms and dysphemism can be produced through strategies inside languages and strategies outside languages. Strategy inside language or linguistic strategy, is a mechanism for the formation of euphemisms that involves elements of semantic meaning such as analogies, distortions, and borrowing where each part have a relationship between one another. Whereas the non-language strategy is the mechanism of replacing a certain lexical by euphemistic expression that caused by things that are outside the language [6]. In a certain context, online media also use different strategies than just presenting euphemisms in their reporting. Especially in evaluative matters. The expression used not only to describe the facts, but also a statement of the attitude of the author (online media) related to what is reported [7]. The use of euphemisms does not always have a positive effect. Conversely, there is a negative impact produced by the use of euphemisms that make things unclear or blurred [8], as well as the dysphemism which is used by online media to form straightforward and blatant opinions. This function is used to reveal real facts about something. Dysphemism has functions such as: 1) attacking the other person, 2) blaming and accusing the other person, 3) denying the other person's opinion, 4) criticizing and evaluating the other person, 4) condemning the other person, 5) convincing a fact to the other person, and 6) expressing incompatibility with the interlocutor [9].

[10] explains the use of euphemisms found in the British National Press by stating that euphemisms function is to build the self-image of local politicians. While the purpose of its use is to avoid things that hurt certain groups and to criticize policy. [11] in her research on euphemism and framing media revealed that lexical creations of euphemisms generally took the form of loan words, expansion of meaning, metonymy, metaphor, ellipsis, irony, using negative prefixes, abbreviations, adaptations, and ambiguity. This study aims to describe and explain lexical creations of euphemism and dysphemism in the online news media on the Presidential Election of Republic of Indonesia in 2019.

\section{Research Method}

The study was qualitative by using case study approach. The object of the study was euphemism and dysphemism expression about Presidential election of republic Indonesia 2019 were appeared in online media. The data sources was taken from online media text, they are: DetikNews, SindoNews, TribunNews, and CNN Indonesia.

The data were analyzed by using framing analysis and componential analysis of semantic. The componential analysis was used because the existence of euphemism and dysphemism cannot be separated from the study of meaning, hence the semantic approach is used to explain the relationship between variables. 


\section{Results And Discussion}

\subsection{Lexical mitigation of Euphemism}

Euphemism is a language expression that replaces expressions that are inappropriate, offensive, even unpleasant with a view to refining, maintaining politeness and the face concern of the other person. This is possible because in daily communication the practice of language is motivated by certain considerations and goals. Certain lexical replacements with other lexical that are degrading, taboo, etc. that soften the meaning referred to as mitigation. As the following data:

(1) Ma'ruf bilang saat ini masih ada yang ingin membenturkan kelompok Islam dan nasionalis (CNN Indonesia)

(2) Paslon nomor urut 02 Prabowo-Sandi mengirimkan perbaikan visi misi ke KPU (CNN Indonesia)

(3) Ia menyebut hanya ada pendetailan dan perincian terhadap program di dalamnya. (CNN Indonesia)

(4) Tapi intinya, kami ingin mempertanyakan kenapa sampai ada pembatasan bagi kami untuk melakukan perubahan visi-misi itu. (SindoNews)

(5) menurut Ketua DPP Partai Keadilan Sejahtera (PKS) ini, penyempurnaan visi misi ini bagian dari pertanggung jawaban publik.( Tribunnews)

(6) ...,yang kita ketemukan ada perasaan di masyarakat bahwa kadang-kadang aparat itu berat sebelah.( Tribunnews)

(7) Riza mengatakan dengan begitu tidak tepat bila dikatakan ada revisi visi dan misi. (SindoNews)

(8) ..masing-masing (yang berbeda pilihan) tidak baper. (SindoNews)

(9) Jadi kalau kemudian Pak Kyai Ma'ruf terbatas,. (Tribunnews)

There are 9 data, each of which is a form of lexical mitigation. In data (1), (2), (3), (4), (5), and (6) italicized words are lexical creations of euphemisms that refine the meaning. Data (1) 'membenturkan' has a polite meaning than 'mengadu' (get into a fight). 'membenturkan' (banging) has a component meaning of inanimate in which it does not have power and desire to fight. While 'mengadu' is use more on animate in which it has desire to fight as a result of 'membenturkan'. The use of 'membenturkan' is more polite than 'mengadu' in terms of bring something into conflict.

Data (2) 'perbaikan' (revise) instead of the lexical 'perubahan' (change) bring the meaning to be soften and be polite. 'perubahan' is rude and coercive. In the context of data (2) 'perubahan' is not used because it shows a behavior that violates the rules that have been set as the closing period of submission of the candidate's vision and mission. The same thing applies to data (3) and (5). In data (4) lexical mitigation occurs from 'melarang' (restrict) to 'pembatasan'. The lexical 'melarang' (forbid) has a component of repressive meaning, confrontation, and showing power. Unlike the 'pembatasan' (limitation) which has meaning components that there is still space and is persuasive. Data (6) 'perasaan' (feeling) has a subtle component of meaning, guessing, and not accentuating the ego. The data will be different when replaced with 'merasa' (feel) which has meaning as object and accuse. Therefore, 'perasaan' is used to express the accusation subtly. Further on the data (1), (2), (3), (4), (5), and (6) are lexical mitigations categorized as affixes.

Data (7), (8), and (9) are also direct lexical replacements. However, in data (8) it has a different word category, which is in the form of acronym. 'Baper' is a slank word which is an 
acronym for 'terbawa perasaan' (carried away). Different categories also occur in data (9), in that they are categorized as superlative as a part of comparative words.

\subsection{Loan words of Euphemism}

Other forms of lexical euphemism are loan words. The lexical is taken from another language that has the same meaning. Soften meaning by using loan words is possible because it can obscure the real meaning of the user language.

(10) .., namun kemudian visi misi itu ditake down (CNN Indonesia)

(11) Risiko suap atau 'hanky panky' (CNN Indonesia)

Data (10) is loan words from English and it is also in a form of blending between loan words that get the prefix ' $d i$-'taken from Bahasa Indonesia. Data (11) is loan words in the form of idiomatic expressions. As an idiomatic function is to make smooth meaning by saying it indirectly.

\subsection{Metaphorical equation of Euphemism}

Metaphor is a direct expression of analogical comparison where the word or phrase used is not the lexical meaning but to describe the comparison or similarity of an object with other objects. Metaphor is also a word or group of words which does not say the word meaning, but as a figure of speech based on an equation or comparison. Metaphor has the characteristics: 1) use words or phrases that have a figurative meaning to equate or compare an object with other objects; 2) comparing an object or situation by using direct comparison without the presence of comparative words such as words like, like, or like; 3) do not use conjunctions. Certain lexical replacements with metaphorical forms become the choice to soften the meaning by using metaphors or comparisons.

(12) Risiko suap atau 'hanky panky' (CNN Indonesia)

(13) tidak ada yang ikhlas rumah kita diambil orang," (detikNews)

(14) terutama kantong-kantong petahana itu mengatakan (detikNews)

(15) 'main sebar' informasi tanpa tabayun. (SindoNews)

(16) Joko Widodo bekerja sendiri dalam pertarungan. (Tribunnews)

(17) aparat itu berat sebelah (Tribunnews)

All the data in the metaphor equation category has an idiomatic meaning, but in data (12) beside having idiomatic meaning it is also an expression taken from another language.

Dysphemism with its open and blatant nature has the opportunity for speakers to convey something that cannot be stated with a certain lexical because it has taboo values etc.[12]. [13] argues that in politics, exaggerating dysphemism is a tool used to describe political opponents in order to have a negative image. Furthermore, dysphemism is also a representation of the negative assessment of an emotional and attacking behavior [14].

\subsection{Lexical mitigation of Dysphemism}

The lexical creation of dysphemism in the form of direct replacement with other words that contains a strike, blatant and attacking meaning makes the meaning of the text become more impolite and being evaluative.

(18) yakni mengganti dokumen resmi (CNN Indonesia)

(19) pihaknya menjiplak visi dan misi pasangan Jokowi-Ma'ruf. (CNN Indonesia)

(20) KPU terburuk dalam sepanjang sejarah (CNN Indonesia) 
(21) Amin menyebut bahwa 'bocoran'. (CNN Indonesia)

(22) Jokowi-Ma'ruf menyerang kubu Prabowo-Sandiaga (CNN Indonesia)

(23) ucapan Sudirman itu dimentahkan PKB (detikNews)

(24) visi-misi itu adalah hasil yang merupakan hasil jiplakan (SindoNews)

Various forms of lexical dysphemism creation in the form of direct replacement make the expression become harsh as found in the data presented above. Data (18) 'mengganti' (replace) has a deliberate meaning, it will be different if the lexical is 'membenahi' (fix) or 'merevisi' (to revise). Likewise, data (19) 'menjiplak' (plagiarized) has the meaning of intentional, trailing, not being able to create by their self. All these meanings make the meaning of the expression become attacking. Data (21) 'bocor' (leak) directs the meaning to something that is out of control, and cannot be dammed. This also happened to data (22), (23) and (24). All of these data are direct lexical replacements in the form of affixes. In contrast to data (20), it is a comparative word that has superlative meaning.

\subsection{Metaphorical equations of Dysphemism}

The use of metaphorical meaning is not only occurring in euphemism, but also in dysphemism. The used of figurative language is not something that is ambiguous, but these expressions are based on something strike, direct, and harsh.

(25) "Supaya (kantong negara) tidak jebol. (CNN Indonesia)

(26) sebagai kandang banteng karena menjadi basis bagi PDIP. (detikNews)

(27) terutama kantong-kantong petahana itu mengatakan, (detikNews)

A figure of speech which has a rough meaning as appeared in data (25) and (26). Whereas data (27) has a bluntly meaning by using figurative expression. 'kantong petahana' (support base) used to refer to the 'basis pendukung petahana' (incumbent supporting base) are straightforward, open and isulting expressions. 'kantong-kantong' (Bags) have analogy of figurative meaning with inanimate objects and clearly visible containers [15].

\subsection{Hyperbole of Dysphemism}

Hyperbole is a statement that exaggerates the fact that it makes no sense. It has become one of the most creative forms of lexicalism to make the receptor language believe and follow the opinions of its speakers. Moreover, it can also be degrading as a result of exaggeration so that the purpose of the use of dysphemism is to bring down the opponent.

(28) "Indonesia saat ini negara yang lemah, (Tribunnews)

\section{Conclusion}

The news on presidential election 2019 in online media has the diversity of each as the expression of euphemism and dysphemism used. The lexical creations of euphemisms that aim to soften meaning, blur meaning, and also maintain politeness is in the form of lexical mitigating in the form of word and affixed words. Apart from that, it can also be an acronym and can also be a superlative. Other forms of lexical euphemism are loan words and metaphorical equations. This is different with the creation of lexical dysphemism which has a category namely: lexical mitigation, metaphorical equation, and hyperbole. Each of these lexical creations has a harsh, outspoken, insult, and attacking meaning. 


\section{References}

[1] Burridge, Kate.. Euphemism and language change. The sixth and seventh ages. Lexis. Journal in English Lexicology 7, 2012

[2] Hojati. Alireza.. A Study of Euphemisms in the Context of English-speaking Media. International Journal of Linguistics. ISSN 1948-5425. 2012, Vol. 4, No. 4. www.macrothink.org/ijl, 2012.

[3] Allan, K., \& Burridge, K. Forbidden words: Taboo and the censoring of language. Cambridge: Cambridge University Press, 2006.

[4] Bakhtiar, M. Communicative Functions of Euphemism in Persian. The Journal in International Social Research 5, 7-12, 2012.

[5] Crespo-Fernandez, E.. Euphemism and political discourse in the British regional press. Brno Studies in English, 40 (1), 5-26. http://dx.doi.org/10.5817/BSE2014-1-1, 2014.

[6] Burridge, Kate.. Euphemism and language change. The sixth and seventh ages. Lexis. Journal in English Lexicology 7, 2012

[7] Albertazzi, L.. Which Semantics? meaning and cognition. A multidisciplinary Approach. Amsterdam and Philadelphia: John Benjamins publishing company, 2000.

[8] Hojati. Alireza.. A Study of Euphemisms in the Context of English-speaking Media. International Journal of Linguistics. ISSN 1948-5425. 2012, Vol. 4, No. 4. www.macrothink.org/ijl, 2012.

[9] Saville. Troike Muriel. The ethnography of communication : an introduction 3rd ed. Blackwell Publishing, 2003.

[10] Crespo-Fernandez, E.. Euphemism and Political Discourse in the British regional press. Brno Studies in English, 40 (1), 5-26. http://dx.doi.org/10.5817/BSE2014-1-, 2014.

[11] Ryabova, M. Euphemism and Media Framing. Eurobean Scientific Journal , 32 (9), 33-44, 2013.

[12] Crespo-Fernandez, E.. Euphemism and Political Discourse in the British regional press. Brno Studies in English, 40 (1), 5-26. http://dx.doi.org/10.5817/BSE2014-1-, 2014.

[13] Van Dijk, Teun. Text and Context: Explorations in the Semantics and Pragmatics of Discourse. London: Longman Group Ltd, 1977.

[14] Crespo-Fernandez, E.. Euphemism and Political Discourse in the British regional press. Brno Studies in English, 40 (1), 5-26. http://dx.doi.org/10.5817/BSE2014-1-, 2014.

[15] K. Saddhono, "Language and superdiversity: Indonesians knowledging at home and abroad. By Zane Goebel." Soc. Stu. vol. 12 no.1 pp. 113-118, 2018 